\title{
Performance Evaluation and Measurement in Public Organizations: A Systematic Literature Review
}

\author{
Francesco Polese ${ }^{1}$, Orlando Troisi ${ }^{1}$, Carlo Torre ${ }^{1} \&$ Gennaro Maione ${ }^{1}$ \\ ${ }^{1}$ University of Salerno, Fisciano, Salerno, Italy \\ Correspondence: Gennaro Maione, University of Salerno, Via Giovanni Paolo II - 84084, Fisciano, Salerno, Italy. Tel: \\ 39-89-963-087.
}

Received: December 30, 2016

Accepted: January 18, $2017 \quad$ Online Published: January 29, 2017

doi:10.5430/ijba.v8n1p106

URL: http://dx.doi.org/10.5430/ijba.v8n1p106

\begin{abstract}
The turbulence of the current competitive environment emphasizes the importance of the role played by performance measurement systems in generating an improvement of business results. Starting from this consideration, the work pursues a twofold goal: firstly, it tries to verify the existence and the degree of a research interest about this topic; secondly, it seeks to identify, in measurement and evaluation systems, which factors are capable of producing an effect on performances of public organizations. In order to well respond to the research purposes, the work begins with a systematic literature review, which highlights a growing attention of scholars on all those variables considered critical in conducting and managing public organizations. The study, highlighting the existence of six variables to be advantageously taken into account in managing public organizations, especially in light of the potential influence that they seem to exert on different types of business performances, could be considered as a useful tool for both practitioners (managers of public organizations) and scholars (professors, researchers, students, etc.) aimed at helping to become aware about the advantages arising from an adequate management of performances measures. The main research limitation is the lack of an empirical analysis of public companies performance plans, which should be thoroughly examined to allow a possible further generalization of the theoretical findings achieved.
\end{abstract}

Keywords: performance, performance evaluation, performance measurement, public organizations, systematic literature review

\section{Introduction}

The turbulence and complexity of the current competitive environment make central the role played by performance measurement systems in generating an improvement of company results (Manning \& White, 2014). The attention given to the development of evaluation and measurement systems stems from the conviction that an adequate management of some conditions could improve performances of companies (Newcomer, Baradei, \& Garcia, 2013; Lynch-Cerullo \& Cooney, 2011; Herranz, 2010), increasing efficiency in the use of their resources and effectiveness in the implementation of their strategies (Li, 2015).

Starting from this consideration, the work pursues a twofold goal: firstly, it tries to verify the existence and the degree of a research interest about this topic; secondly, it seeks to identify, in measurement and evaluation systems, which factors are capable of producing a positive or negative effect on performances of public organizations.

The paper consists of three sections: at first, it deploys a systematic literature review, used for locating, sorting, collecting and analysing contributions considered relevant for the research purposes; later, it describes the results obtained with regard to the interest of academic world about the measurement and evaluation of business performances and variables considered influential in shaping positively or negatively performance of public organizations; finally, conclusions are presented, highlighting both paper limitations and ideas for future research.

\section{Methodology: Systematic Literature Review}

In order to well respond to the research objectives, the work begins with a systematic literature review on the assessment and measurement of public organizations performance. The decision to resort to this method rather than to a non-systematic review is basically due to the attempt to develop a subsequent discussion about the existence of a real academic interest in the stimulus factors of business performances, starting from a set of contributions strictly selected, i.e. minimizing the discretion in the choice of contributions to be analysed. 
The review has been conducted by defining and then applying several inclusion criteria to potentially traceable literature. To this end, only contributions focused on the theme of performance evaluation and measurement have been selected.

The collection has been carried out on the database "Web of Science", by inserting, as a first step, in the field TOPIC, three key words by means of the Boolean operator $A N D$ : "Performance", "Evaluation" and "Measurement". In doing so, the database has provided 25787 records.

Subsequently, the research has been refined by limiting it only to the interest area, "Public Administration", giving back 121 items.

To further calibrate the research consistently with the aforementioned objectives and avoid interpretative biases related to conceptualizations by now "obsolete" about the identification of influencing factors of business performances, the selection has been prosecuted by limiting the time span and, specifically, considering only contributions published in the period between 2000 and 2015. The contributions published in 2016 have been ignored due to incomplete information given by the fact that the reference period is still ongoing. The use of a time filter has determined a further skimming, allowing narrowing down the field of analysis to 108 occurrences.

The criteria used for the identification of contributions to be analysed have not taken into account the ranking of journals, in order to avoid forgetting items possibly relevant, although published in journals with not particularly high impact factor. Therefore, all journals found on the chosen database have been included in the research. However, neither "grey literature" nor books or book chapters have been considered: attention has been paid only to papers published on international journals. This further inclusion criterion has reduced to 74 the number of contributions previously identified.

In addition, to allow the replicability of the review and ensure that all records included in the analysis had an international audience, only contributions written in English have been selected, obtaining, thereby, a set of 69 items.

Based on the titles and abstracts of the identified papers, finally, the authors have further streamlined the number of contributions, considering only those containing a reference to one or more determinants that, directly or indirectly, could, at least theoretically, influence public organizations performances, both in conceptual and empirical terms. The latter selection criterion have led to the inclusion of 35 paper.

The above-described steps are summarized in a flow chart (Figure 1), representative of the selection process adopted for the systematic literature review:

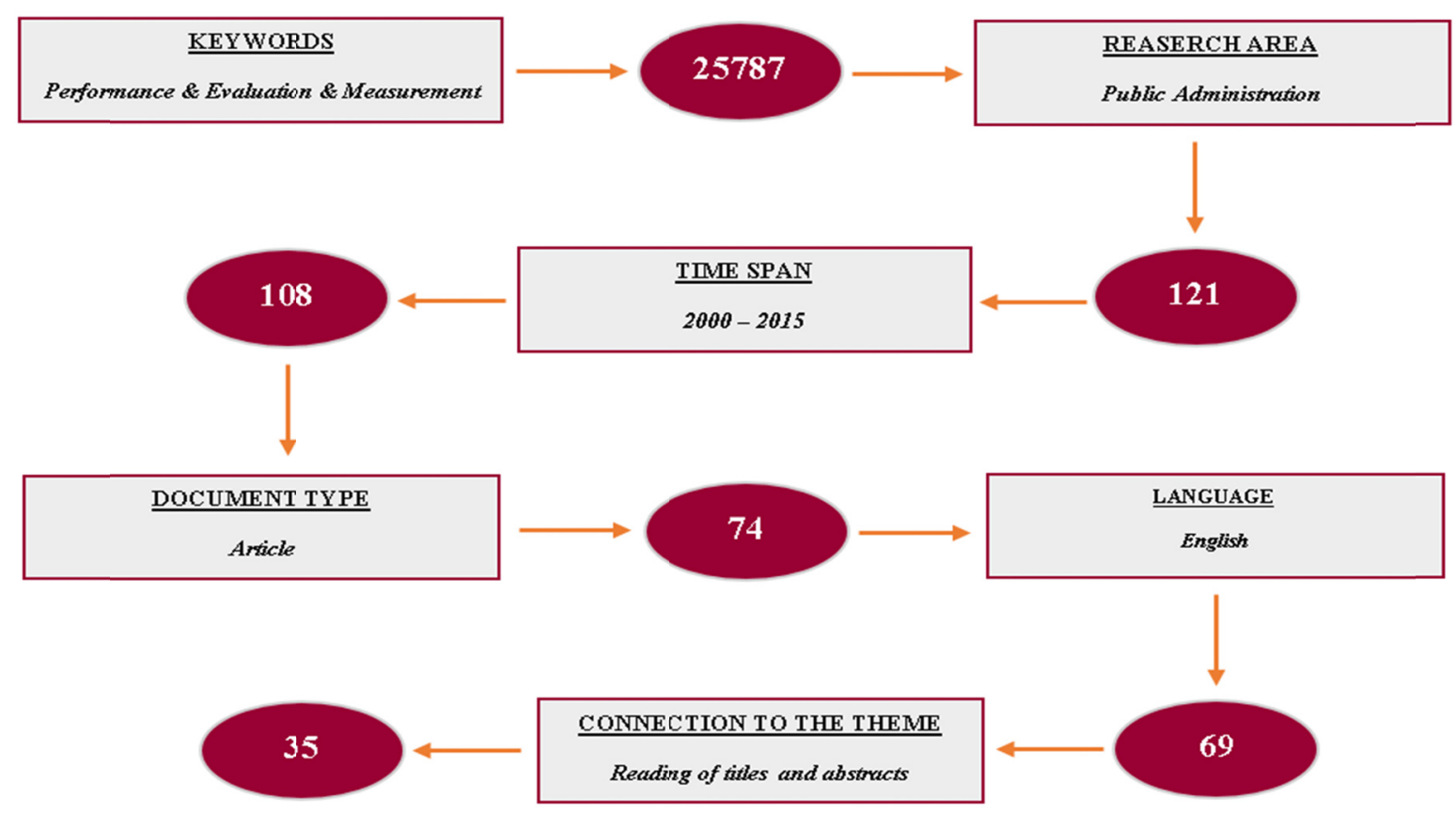

Figure 1. Flowchart of systematic literature review 
The full text of the selected papers has been recovered from "Web of Science" and, when not available, from external sources. The Table 1 shows the title, authors, name of journal and (decreasing) publication date of each of the 35 selected articles:

Table 1. Selected papers

\section{TITLE}

AUTHOR(S)

JOURNAL

DATE

Use and Utilization of Performance Information in Hungary: Exemplary Cases from the Local-Government and the Higher-Education Sectors

Performance Management and Performance Appraisal: Czech Self-Government

Measuring for Absorption: How the Institutionalisation of EU Cohesion Policy Influences the Use of Performance Indicators in Hungary

The paradox of performance regimes: strategic responses to target regimes in Chinese local government

External government performance evaluation in China: a case study of the 'Lien service-oriented government project

Policy Evaluation via Composite Indexes: Qualitative Lessons from International Transparency Policy Indexes

External Government Performance Evaluation in China: Evaluating the Evaluations

Measuring Social Return on Investment

Measuring E-government performance of provincial government website in China with slacks-based efficiency measurement

The 'logic of escalation' in performance measurement: An analysis of the dynamics of a research evaluation system

Measuring results in development: the role of impact evaluation in agency-wide performance measurement systems

Hajnal \&
Ugrósdy
Špalková,
Špaček, \&
Nemec

Nemec

Mike \&

Balás

$\&$

Balas

$\mathrm{Li}$

Yu \& Ma

Michener

Yu \& Ma

Moody,

Littlepage, \& Paydar

Wu \& Guo

Woelert

Manning \&

White
NISPACEE JOURNAL OF PUBLIC

2015

ADMINISTRATION AND

POLICY

NISPACEE JOURNAL OF PUBLIC

ADMINISTRATION AND

POLICY

NISPACEE JOURNAL OF

PUBLIC

ADMINISTRATION AND

2015

POLICY

PUBLIC

ADMINISTRATION

2015

PUBLIC MONEY \& MANAGEMENT

2015

WORLD DEVELOPMENT

2015

PUBLIC PERFORMANCE \& MANAGEMENT 2015

REVIEW

NONPROFIT

MANAGEMENT \& 2015

LEADERSHIP

TECHNOLOGICAL FORECASTING AND

2015

SOCIAL CHANGE

POLICY AND SOCIETY

2015

JOURNAL $\mathrm{OF}$ DEVELOPMENT EFFECTIVENESS 
Balancing accountability and learning: a review of Oxfam GB's global performance framework

New public service performance management tools and public water governance: the main lessons drawn from action research conducted in an urban environment

The case of performance measurement in mobility management programs

Alignment of performance measurement to sustainability objectives: A variance-based framework

Expectations and capacity of performance measurement in ngos in the development context

Learning as a Key to Citizen-centred Performance Improvement: A Comparison between the Health Service Centre and the Household Registration Office in Taipei City

Performance measuring in social enterprises

The logic model as a tool for developing a network performance measurement system

You Learn From What You Measure: Financial and Non-financial Performance Measures in Multinational Companies

Performance measurement and the search for best practices

Performance Measurement in European local governments: a comparative analysis of reform experiences in Great Britain, France, Sweden and Germany

Supporting program management by developing, implementing, and transferring knowledge from the performance indicator monitoring system (PIMS)

Collaborative Performance Measurement: Examining and Explaining the Prevalence of Collaboration in State and Local Government Contracts

$\begin{array}{lll} & \text { JOURNAL } & \text { OF } \\ \text { Hutchings } & \text { DEVELOPMENT } & \\ & \text { EFFECTIVENESS } & \\ & & \\ \text { Tabi \& } \quad \text { INTERNATIONAL } & \\ \text { Verdon } & \text { REVIEW } & \text { OF } \\ & \text { ADMINISTRATIVE } & \\ & \text { SCIENCES } & \end{array}$

Majumdar,

Sen, Highsmith, \&

Cherington

Dutta,
Lawson, \&
Marcinko

Newcomer,

El Baradei,

\& Garcia

So

OF PUBLIC
ADMINISTRATION

2012

Bagnoli \& Megali

NONPROFIT VOLUNT

2011

Herranz

PUBLIC PERFORMANCE \& MANAGEMENT REVIEW

Dossi \& LONG RANGE Patelli PLANNING

INTERNATIONAL

De Vries

REVIEW

OF

ADMINISTRATIVE

2010

SCIENCES

INTERNATIONAL

Kuhlmann

REVIEW OF

ADMINISTRATIVE

2010 SCIENCES

Arh \&

PUBLIC PERFORMANCE Schwartz REVIEW

2009

THE AMERICAN

Carman REVIEW OF PUBLIC 
Performance measurement: Examining the applicability of the existing body of knowledge to nonprofit organizations.

Advancing nonprofit organizational effectiveness research and theory: Nine theses

Performance regimes-The institutional context of performance policies

A conceptual framework to evaluate performance of nonprofit social service organizations

The performance-trust link: Implications for performance measurement

Falling from a great height: Principles of good practice in performance measurement and the perils of top down determination of performance indicators

No longer unmeasurable? A multidimensional integrated model of nonprofit organizational effectiveness

The public value scorecard: a rejoinder and an alternative to 'strategic performance measurement and management in non-profit organizations'

Mission impossible?: Measuring success in nonprofit organizations

Strategic performance measurement and management in nonprofit organizations

Measuring the performance of voluntary organizations.
INTERNATIONAL

JOURNAL OF

Moxham

OPERATIONS

\&

2009

PRODUCTION

MANAGEMENT

Herman \&
Renz

NONPROFIT

MANAGEMENT AND 2008

LEADERSHIP

INTERNATIONAL

Talbot JOURNAL OF PUBLIC 2008

ADMINISTRATION

Median-Bor

INTERNATIONAL

ja, A., \&

JOURNAL

OF

TECHNOLOGY

2007

MANAGEMENT

PUBLIC

Yang \&

Holzer

ADMINISTRATION

REVIEW

2006

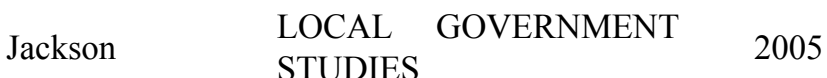

Sowa, NONPROFIT AND

Selden, \& VOLUNTARY SECTOR

2004

Sandfort

QUARTERLY

Moore

HAUSER CENTER FOR

NONPROFIT

2003

ORGANIZATIONS

Sawhill \&

NONPROFIT

Williamson

MANAGEMENT

AND

2001

LEADERSHIP

NONPROFIT

Kaplan

MANAGEMENT

AND

2001

LEADERSHIP

Kendall \& PUBLIC MANAGEMENT

Knapp

\section{Data Analysis}

The analysis highlights, firstly, an increasing attention of scholars to all those variables considered critical in conducting and managing public organizations. Such a statement is widely supported by the fact that, as shown in the Table 2, in recent years, with few exceptions, the number of contributions about performances evaluation and measurement of companies operating in public sector has generally grown exponentially. Only in 2015, in fact, there is around one third $(28.6 \%)$ of the 35 scientific articles selected since 2000 . 
Table 2. Trend of the selected papers about performance evaluation and measurement of public organizations

\begin{tabular}{ccc}
\hline PUBLICATION DATE & OCCURENCES & $\boldsymbol{\%}$ \\
\hline 2015 & 10 & 28.571 \\
2010 & 4 & 11.114 \\
2014 & 3 & 8.571 \\
2013 & 3 & 8.571 \\
2009 & 3 & 8.571 \\
2008 & 2 & 5.714 \\
2001 & 2 & 5.714 \\
2012 & 1 & 2.857 \\
2011 & 1 & 2.857 \\
2007 & 1 & 2.857 \\
2005 & 1 & 2.857 \\
2006 & 1 & 2.857 \\
2004 & 1 & 2.857 \\
2003 & 1 & 2.857 \\
2001 & 1 & 2.857 \\
\hline
\end{tabular}

The orientation emerging from Table 2, however, cannot be assessed in absolute terms. In fact, it needs to be appropriately compared with the total number of international scientific publications, which has gradually increased over time (Figure 2).

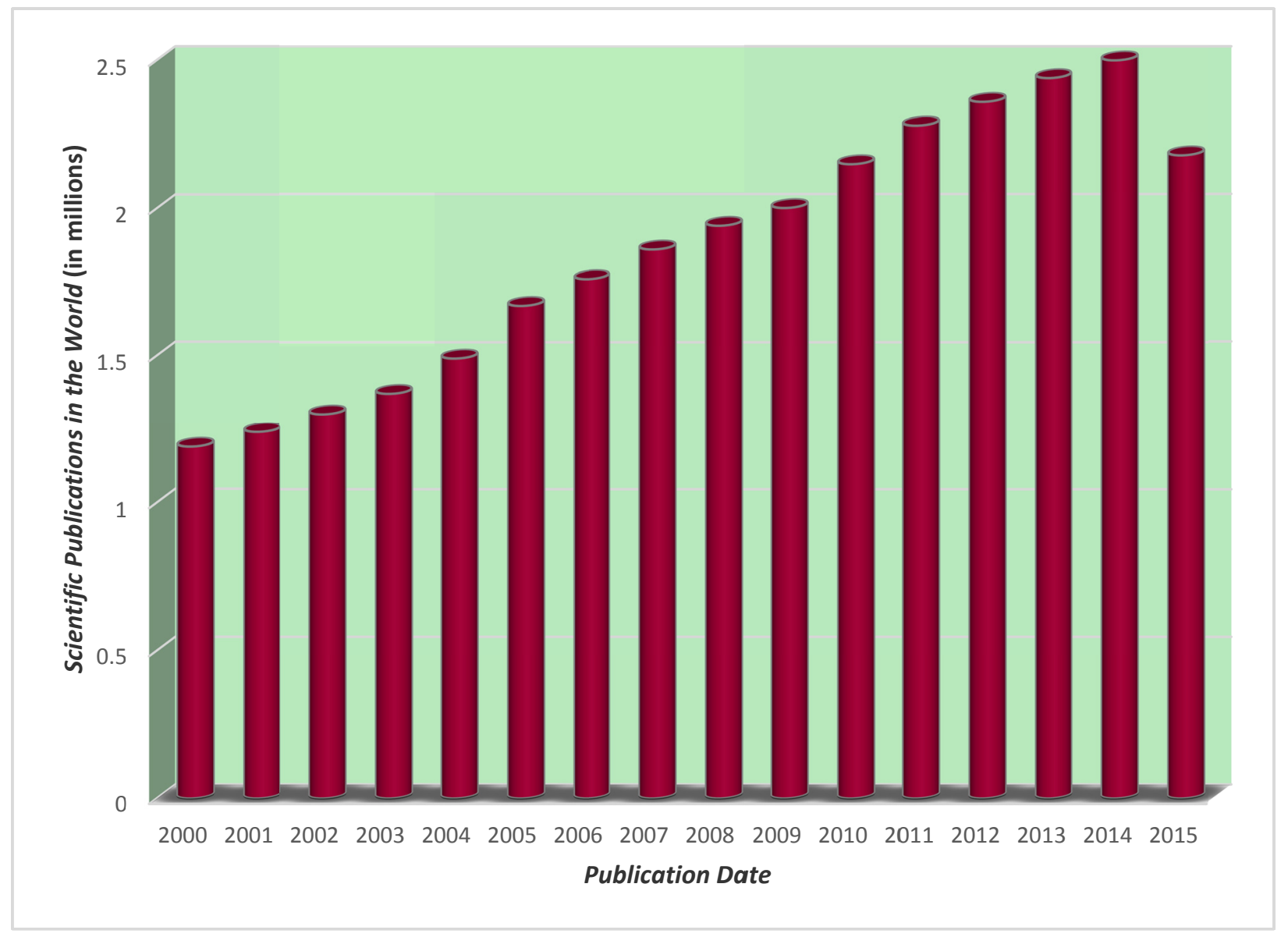

Figure 2. Overall trend of scientific publications in the world (Note 1)

Source: Reworking of the data published on http://www.scimagojr.com/ 
On the other hand, however, a massive and growing interest of academic world to the topic of performance and evaluation measurement in public sector, since the number of international scientific contributions published in 2015 is less than $28,6 \%$ of the total, as, instead, is for articles published in the same year compared with the pre-selected 35 ones.

Another datum arising from the systematic literature review carried out is that about $68.35 \%$ of the selected articles has been published in four countries: USA, UK, China and Germany, demonstrating the considerable importance recognised in the aforementioned countries to the theme of performance evaluation and measurement of public organizations (Table 3).

Table 3. Distribution by country of the 35 scientific papers on the topic of performance evaluation and measurement of public organizations (Note 2)

\begin{tabular}{ccc}
\hline COUNTRY & OCCORRENCES & $\%$ \\
\hline USA & 14 & 40.000 \\
UK & 6 & 17.143 \\
CHINA & 2 & 5.714 \\
GERMANY & 2 & 5.714 \\
\hline Total & 24 & 68.571 \\
\hline
\end{tabular}

Also in this case, the meaningfulness of the results produced by the geographical distribution of the 35 identified articles requires a comparison with the total number of all scientific contributions published in different countries. To this end, it could be useful to observe the Table 4:

Table 4. Scientific publications in the world

\begin{tabular}{ccc}
\hline RANKING & COUNTRY & $\mathbf{N}^{\circ}$ OF SCIENTIFIC PUBLICATION \\
\hline 1 & USA & 9360233 \\
2 & CHINA & 4076414 \\
3 & UK & 2624530 \\
4 & GERMANY & 2365108 \\
5 & JAPAN & 2212636 \\
6 & FRANCE & 1684479 \\
7 & CANADA & 1339471 \\
8 & ITALY & 1318466 \\
9 & INDIA & 1140717 \\
10 & SPAIN & 1045796 \\
\hline
\end{tabular}

Source: Reworking of the data published on http://www.scimagojr.com/

As it is possible to see, in line with the findings related to the set of the selected items, also at overall level, USA, UK, China and Germany are among the top four positions in the world as regards the number of scientific publications. However, it is anyway significant that more than two third of the 35 selected papers has been published in only four countries, also taking into account that the percentage of the world scientific works overall published in them is surely lower than $68.35 \%$. 


\section{Discussion}

The content analysis of the 35 selected articles shows that there are different theoretical approaches to performance evaluation and measurement of organizations, depending on the sector (public or private) to which they belong.

Some scholars (Špalková, Špaček, \& Nemec, 2015; Yu \& Ma, 2015; Arh \& Schwartz, 2009; Shingler, Van Loon, Alter, \& Bridger, 2008), in fact, point out that performance evaluation and measurement of public organizations is, as far as possible, even more complex than private one, since these entities pursue multiple objectives, which, going beyond the mere economic enrichment, often are very difficult to be measured (Boyne, Gould-Williams, Law, \& Walker, 2002). However, the continuous pressures suffered by public organizations have pushed management scholars to focus on the assessment and measurement of their performances (Wu \& Guo, 2015; Kuhlmann, 2010; Yang \& Holzer, 2006; Jackson, 2005; Kelly \& Swindell, 2002; Sanderson, 2001).

Many of the selected studies are consistent with the idea that the use of information necessary for decision making can be facilitated by developing innovative and advanced performance measurement techniques (Woelert, 2015; Tabi \& Verdon, 2014; Hutchings, 2014). The need to comprehensively assess performancees of organizations operating in public sector and the importance traditionally attached to them, in fact, have gradually confined the scholars' attention not only on economic and technical aspects, but also on social and, especially in recent times, environmental ones. Therefore, the purpose of performance evaluation and measurement techniques becomes (also) to provide information to guide decision-making activities in effective and sustainable way (Hajnal \& Ugrosdy, 2015).

In this regard, other academics (Dutta, Lawson, \& Marcinko, 2013) state that, for the purposes of their effectiveness, performance measures should be congruent with the objectives pursued by organization, controllable by managers to influence organization behaviour, timely, accurate and efficient in terms of costs. Consistently, Julnes and Holzer (2001) observe that the acquisition of information about performances can diffusely contribute to improve organizational learning.

The 35 identified studies show the existence of different types of performances of organizations operating in public sector, of which the main ones are listed in the Table 5. Specifically, the authors have analysed the content of the selected contributions and have extracted all information about the several kinds of performance and their relative description, synthetizing them in six new categories, within each, moreover, several measures, understood as structural conditions potentially capable of facilitating the achievement of performance, have been identified.

Table 5. Variables that could affect performances of public organizations

\begin{tabular}{|c|c|c|}
\hline $\begin{array}{l}\text { PERFORMANCE } \\
\text { CATEGORIES }\end{array}$ & MISURES & REFERENCES \\
\hline $\begin{array}{l}\text { AVAILABILITY OF } \\
\text { RESOURCES }\end{array}$ & 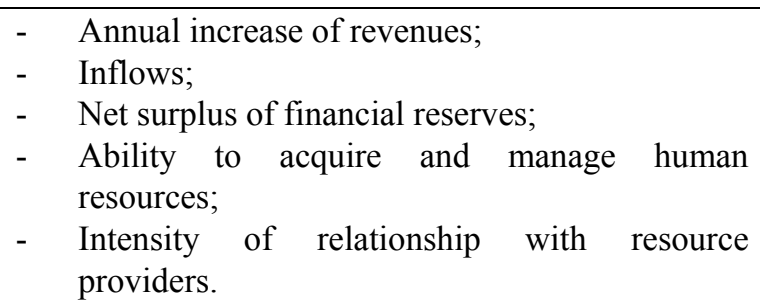 & $\begin{array}{llll}\text { Bagnoli \& } & \text { Megali } & (2011) ; \\
\text { Kendall \& } & \text { Knapp } & (2000) ; \\
\text { Median-Borja \& } & \text { Triantis } \\
\text { (2007). } & & \end{array}$ \\
\hline $\begin{array}{l}\text { CAPACITY OF } \\
\text { MAKING } \\
\text { PRODUCTS }\end{array}$ & $\begin{array}{l}\text { - Punctuality of deliveries; } \\
\text { - } \text { Reached achievements in relation to the } \\
\text { services offered; } \\
\text { - } \\
\text { - } \text { Usumber of users served; } \\
\text { - } \\
\text { - } \text { Frequency onse times: } \\
\text { Quality of services provided } \\
\text { cultural accessibility - timeliness operators' } \\
\text { courtesy - condition of structures. }\end{array}$ & $\begin{array}{l}\text { Kendall \& Knapp (2000); } \\
\text { Moxham (2009); Sawhill \& } \\
\text { Williamson (2001). }\end{array}$ \\
\hline
\end{tabular}




\begin{tabular}{|c|c|c|}
\hline & $\begin{array}{ll}- & \text { Staff satisfaction; } \\
\text { - } & \text { Staff training; }\end{array}$ & Kaplan \\
\hline $\begin{array}{l}\text { ORGANIZATIONAL } \\
\text { SKILL }\end{array}$ & $\begin{array}{l}\text { - Staff executive and operative capabilities; } \\
\text { - Cost, quality and cycle times of critical } \\
\text { processes; }\end{array}$ & $\begin{array}{l}\text { (2003); Sowa, Selden, \& } \\
\text { Sandfort (2004). }\end{array}$ \\
\hline
\end{tabular}

\begin{tabular}{|c|c|c|}
\hline $\begin{array}{l}\text { RESULTS IN } \\
\text { TERMS OF USERS } \\
\text { SATISFACTION }\end{array}$ & $\begin{array}{l}\text { Customer satisfaction; } \\
\text { Customer loyalty; } \\
\text { Ability to acquire new customers. }\end{array}$ & $\begin{array}{l}\text { Penna (2011); Median-Borja } \\
\text { \& Triantis (2007); Poister } \\
\text { (2003); Kaplan (2001);; } \\
\text { Newcomer (1997); }\end{array}$ \\
\hline $\begin{array}{l}\text { RESULTS IN } \\
\text { TERMS OF } \\
\text { BEHAVIOURAL } \\
\text { AND } \\
\text { ENVIRONMENTAL } \\
\text { CHANGE }\end{array}$ & $\begin{array}{l}\text { Increase of skills and knowledge; } \\
\text { Improvement of starting conditions; } \\
\text { Behavioral changes: impact on misconduct, a } \\
\text { percentage of desirable behaviour, maintenance } \\
\text { of new behavior. }\end{array}$ & 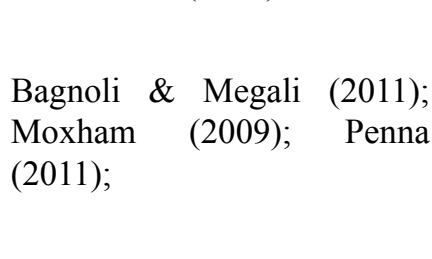 \\
\hline $\begin{array}{l}\text { PROPENSITY TO } \\
\text { BUILD } \\
\text { RELATIONAL } \\
\text { NETWORKS }\end{array}$ & $\begin{array}{l}\text { Relations with the funders } \\
\text { Success stories in terms of partnership } \\
\text { Consistency of activities with the mission of } \\
\text { organization. }\end{array}$ & $\begin{array}{l}\text { Bagnoli \& Megali }(2011) \text {; } \\
\text { Herman \& Renz (2008); } \\
\text { Talbot (2008); Moore (2003). }\end{array}$ \\
\hline
\end{tabular}

\section{Implications and Conclusion}

The work, in an attempt to offer a systematization of the literature about performance evaluation and measurement, tries to achieve an identification of the only variables effectively connected to performances of public organizations.

As showed in Table 5, there are six variables to be advantageously taken into account in managing public organizations, especially in light of the potential influence that they seem to exert on different types of business performances (Moody, Littlepage, \& Paydar, 2015; Majumdar, Sen, Highsmith, \& Cherrington, 2013; Dossi \& Patelli, 2010; Schochet \& Burghardt, 2008; Savaya \& Waysman, 2005; Voytek, Lellock, \& Schmit, 2004):

$>$ Availability of resources, understood as the ability of an organization to acquire necessary financial and non-financial resources, using them efficiently to pursue resilience, growth and long term sustainability (Kendall \& Knapp, 2000). In this regard, according to Mao et al. (2016), the appropriate resource management is the real key to the success of any organization, public and private. In fact, having adequate resources, both in quantitative and qualitative terms, allows minimizing the dangerous risks in pursuing the organization's mission. Therefore, according to what emerges from the analysis, in order to facilitate the achievement of the objectives, management should pay attention to the following five "measures": annual increase of revenues; inflows; net surplus of financial reserves; ability to acquire and manage human resources; and intensity of relationship with resource providers.

$>$ Capacity of making products, related to the specification quality of goods/services supplied by organizations with regard to the activities having a direct connection with its mission (Sawhill \& Williamson, 2001). In this regard, it is worth specifying that the term "product" refers not only to physical goods, but also the intangible services. Indeed, according to several studies (Vargo and Lusch, 2004; Troisi et al., 2016; Loia et al., 2016), actually, all organizations provide a service, since consumers are interested in the immaterial benefits arising from the use of the products they purchase. Therefore, with regard to the capacity of making products, organizations need to consider: punctuality of deliveries; reached achievements in relation to the services offered; number of users served; users' response times; frequency of services provided; and quality of services provided (such as physical and cultural accessibility, timeliness operators' courtesy, and condition of structures).

$>$ Organizational skill, defined by Sowa, Selden, \& Sandfort (2004) as the human and structural capacity enhancing the capability of organizations to offer programs and services. Precisely, the systematic literature review highlights the need to take into account, besides cost, quality and cycle times of critical processes, especially staff satisfaction, staff training, staff executive and operative capabilities. As it is possible to see, great relevance is attached to organization's staff, understood as the hub of organizational success (Richman et al., 1988). 
$>$ Results in terms of users' satisfaction, which measures the customers' satisfaction degree achieved by organization via its market behaviour (Median-Borja \& Triantis, 2007). According to Reinartz et al. (2004), in fact, customers are the true point of reference of any business strategy: organizations should point to retain customers by offering them goods/services capable of meeting their expectations and interests. Only in this way, hence, it will be possible to obtain performance capable of facilitate the achievement or maintenance of a favorable competitive position. In this regard, the findings of the study indicate three measures of the performance "users' satisfaction": customer satisfaction, customer loyalty and ability to acquire new customers.

$>$ Results in terms of behavioural and environmental change, assessed by considering the status of the target population or condition influenced by a program, with reference to the benefits achieved thanks to organizational activities (Penna, 2011)). Specifically, results in terms of behavioural and environmental change consists of three measures: increase of skills and knowledge; improvement of starting conditions; and behavioral changes (impact on misconduct, a percentage of desirable behaviour, maintenance of new behavior)

Propensity to build relational networks, defined by Herman \& Renz (2008) as the capability of focusing on the positive relationship with other organizations participating in value generation process. In particular, to obtain a positive performance, organizations should show strongly dynamic in adapting their structure to the external environment changes, opening up to the latter by means of the establishment of solid and long-lasting relationships, capable of ensuring numerous advantages in terms of bargaining power, economies of scale, climate of trust, etc. The measures identified through the systematic literature review with regard to the propensity to build relational networks are the following three: relations with the funders; success stories in terms of partnership; and consistency of activities with the mission of organization.

In light of these six performance variables emerged from the systematic literature review, thus, the paper could be considered as a useful tool for both practitioners (managers of public organizations) and scholars (professors, researchers, students, etc.) aimed at helping to become aware about the advantages arising from an adequate management of performances measures.

However, this is what emerges from a purely theoretical point of view and, thus, there could be practical implications in whole or in part different. In other words, it may happen that, although widely shared by international literature (Mike \& Balas, 2015; Michener, 2015; De Vries, 2010; Carman, 2009; Amirkhanyan, 2008), some of the considered variables, theoretically incisive in terms of organization performance, in reality are rarely considered or even ignored in conducting public organizations.

This consideration introduces the main limit of the present study, linkable to the lack of an empirical analysis of corporate performance plans, which, to be fair, should be examined in depth to allow for a possible further generalization of the findings emerged under a theoretical profile. The other weakness of the work is the realization of a systematic literature review on evaluation and measurement performance systems without taking into consideration neither "gray literature" nor books or book chapters, but only papers published on journals, extrapolated, inter alia, from a single database.

Therefore, it might be appropriate, in future researches, to support the theoretical analysis of all types of scientific publications present on more than one database with an empirical observation of business plans, in order to concretely identify all those variables that affect results achievable by adequately managing organizations operating in public sector.

\section{References}

Arh, G., \& Schwartz, R. (2009). Supporting Program Mana gement by Developing, Implementing, and Transfering Knowledge from the Performance Indicator Monitoring System (PIMS). Public Performance \& Management Review, 33(2), 241-254. https://doi.org/10.2753/PMR1530-9576330204

Bagnoli, L., \& Megali, C. (2011). Performance measuring in social enterprises. Nonprofit Volunt. Sect. Q, 40(1), 149-165. https://doi.org/10.1177/0899764009351111

Carman, J. G. (2009). Nonprofits, Funders, and Evaluation Accountability in Action. The American Review of Public Administration, 39(4), 374-390. https://doi.org/10.1177/0275074008320190

De Vries, M. S. (2010). Performance measurement and the search for best practices. International Review of Administrative Sciences, 76(2), 313-330. https://doi.org/10.1177/0020852309365668

Dossi, A., \& Patelli, L. (2010). You learn from what you measure: financial and non-financial performance measures in multinational companies. Long Range Planning, 43(4), 498-526. https://doi.org/10.1016/j.lrp.2010.01.002 
Dutta, S. K., Lawson, R. A., \& Marcinko, D. J. (2013). Alignment of performance measurement to sustainability objectives: A variance-based framework. Journal of Accounting and Public Policy, 32(6), 456-474. https://doi.org/10.1016/j.jaccpubpol.2013.08.008

Hajnal, G., \& Ugrósdy, M. (2015). Use and Utilization of Performance Information in Hungary: Exemplary Cases from the Local-Government and the Higher-Education Sectors. NISPAcee Journal of Public Administration and Policy, 8(2), 23-48. https://doi.org/10.1515/nispa-2015-0007

Herman, R. D., \& Renz, D. O. (2008). Advancing nonprofit organizational effectiveness research and theory: Nine theses. Nonprofit Management and Leadership, 18(4), 399-415. https://doi.org/10.1002/nml.195

Herranz, Jr, J. (2010). The logic model as a tool for developing a network performance measurement system. Public Performance \& Management Review, 34(1), 56-80. https://doi.org/10.2753/PMR1530-9576340104

Hutchings, C. (2014). Balancing accountability and learning: a review of Oxfam GB's global performance framework. Journal of Development Effectiveness, 6(4), 425-435. https://doi.org/10.1080/19439342.2014.971552

Jackson, A. (2005). Falling from a great height: Principles of good practice in performance measurement and the perils of top down determination of performance indicators. Local Government Studies, 31(1), 21-38. https://doi.org/10.1080/0300393042000332837

Kaplan, R. S. (2001). Strategic performance measurement and management in nonprofit organizations. Nonprofit management and Leadership, 11(3), 353-370. https://doi.org/10.1002/nml.11308

Kendall, J., \& Knapp, M. (2000). Measuring the performance of voluntary organizations. Public Management Review, 2(1), 105-132. https://doi.org/10.1080/14719030000000006

Kuhlmann, S. (2010). Performance Measurement in European local governments: a comparative analysis of reform experiences in Great Britain, France, Sweden and Germany. International Review of Administrative Sciences, 76(2), 331-345. https://doi.org/10.1177/0020852310372050

Li, J. (2015). The Paradox of Performance Regimes: Strategic Responses to Target Regimes in Chinese Local Government. Public Administration, 93(4), 1152-1167. https://doi.org/10.1111/padm.12197

Loia V., Maione G., Tommasetti A., Torre C., Troisi O. \& Botti A. (2016). Toward Smart Value Co-education Smart Education and e-Learning 2016. Springer International Publishing, 61-71. Retrieved from http://link.springer.com/chapter/10.1007/978-3-319-39690-3_6

Majumdar, S. R., Sen, L., Highsmith, M. K., \& Cherrington, L. (2013). The Case of Performance Measurement in Mobility Management Programs. Public Performance \& Management Review, 37(2), 280-301. https://doi.org/10.2753/PMR1530-9576370205

Manning, R., \& White, H. (2014). Measuring results in development: the role of impact evaluation in agency-wide performance measurement systems. Journal of Development Effectiveness, 6(4), 337-349. https://doi.org/10.1080/19439342.2014.989673

Mao, H., Liu, S., Zhang, J., \& Deng, Z. (2016). Information technology resource, knowledge management capability, and competitive advantage: the moderating role of resource commitment. International Journal of Information Management, 36(6), 1062-1074. https://doi.org/10.1016/j.ijinfomgt.2016.07.001

Medina-Borja, A., \& Triantis, K. (2006). A conceptual framework to evaluate performance of non-profit social service organizations. International Journal of Technology Management, 37(1-2), 147-161. Retrieved from http://www.inderscienceonline.com/doi/abs/10.1504/IJTM.2007.011808

Michener, G. (2015). Policy Evaluation via Composite Indexes: Qualitative Lessons from International Transparency Policy Indexes. World Development, 74, 184-196. https://doi.org/10.1016/j.worlddev.2015.04.016

Mike, K., \& Balás, G. (2015). Measuring for Absorption: How the Institutionalisation of EU Cohesion Policy Influences the Use of Performance Indicators in Hungary. NISPAcee Journal of Public Administration and Policy, 8(2), 125-147. https://doi.org/10.1515/nispa-2015-0012

Moody, M., Littlepage, L., \& Paydar, N. (2015). Measuring Social Return on Investment. Nonprofit Management and Leadership, 26(1), 19-37. https://doi.org/10.1002/nml.21145

Moore, M. H. (2003). The public value scorecard: a rejoinder and an alternative to'strategic performance measurement and management in non-profit organizations' by Robert Kaplan. Hauser Center for Nonprofit Organizations Working Paper, (18). https://doi.org/10.2139/ssrn.402880 
Moxham, C. (2009). Performance measurement: Examining the applicability of the existing body of knowledge to nonprofit organizations. International Journal of Operations \& Production Management, 29(7), 740-763. https://doi.org/10.1108/01443570910971405

Newcomer, K., Baradei, L. E., \& Garcia, S. (2013). Expectations and capacity of performance measurement in NGOs in the development context. Public Administration and Development, 33(1), 62-79. https://doi.org/10.1002/pad.1633

Reinartz, W., Krafft, M., \& Hoyer, W. D. (2004). The customer relationship management process: Its measurement and impact on performance. Journal of marketing research, 41(3), 293-305. https://doi.org/10.1509/jmkr.41.3.293.35991

Richman, G. S., Riordan, M. R., Reiss, M. L., Pyles, D. A., \& Bailey, J. S. (1988). The effects of self - monitoring and supervisor feedback on staff performance in a residential setting. Journal of Applied Behavior Analysis, 21, 4, 401-409. https://doi.org/10.1901/jaba.1988.21-401

Sawhill, J. C., \& Williamson, D. (2001). Mission impossible?: Measuring success in nonprofit organizations. Nonprofit management and leadership, 11(3), 371-386. https://doi.org/10.1002/nml.11309

So, B. W. Y. (2012). Learning as a key to citizen-centred performance improvement: a comparison between the health service centre and the household registration office in Taipei City. Australian Journal of Public Administration, 71(2), 201-210. https://doi.org/10.1111/j.1467-8500.2012.00769.x

Sowa, J. E., Selden, S. C., \& Sandfort, J. R. (2004). No Longer Unmeasurable? A Multidimensional Integrated Model of Nonprofit Organizational Effectiveness. Nonprofit and Voluntary Sector Quarterly. https://doi.org/10.1177/0899764004269146

Špalková, D., Špaček, D., \& Nemec, J. (2015). Performance Management and Performance Appraisal: Czech Self-Governments. NISPAcee Journal of Public Administration and Policy, 8(2), 69-88. https://doi.org/10.1515/nispa-2015-0009

Tabi, M. T., \& Verdon, D. (2014). New public service performance management tools and public water governance: the main lessons drawn from action research conducted in an urban environment. International Review of Administrative Sciences, 80(1), 213-235. https://doi.org/10.1177/0020852313511574

Talbot, C. (2008). Performance regimes-The institutional context of performance policies. Intl Journal of Public Administration, 31(14), 1569-1591. https://doi.org/10.1080/01900690802199437

Troisi O., Carrubbo L., Maione G. \& Torre C. (2016). The more, the merrier: Co-Working as practical expression of Value Co-Creation in Sharing Economy. XXVI RESER conference, 1130-1144. Retrieved from https://www.researchgate.net/profile/Paula_Guerra5/publication/310060218_Reviving_DIY_The_importance_o f_do_it_yourself_to_the_Portuguese_alternative_rock_scene/links $/ 582873 \mathrm{fe} 08 \mathrm{ae} 950 \mathrm{ace} 6 \mathrm{fae} 49 . \mathrm{pdf} \#$ page $=1142$

Vargo S.L. \& Lusch R.F. (2004). Evolving to a new dominant logic for marketing, Journal of marketing, 68, 1-17. https://doi.org/10.1509/jmkg.68.1.1.24036

Woelert, P. (2015). The 'logic of escalation'in performance measurement: An analysis of the dynamics of a research evaluation system. Policy and Society, 34(1), 75-85. https://doi.org/10.1016/j.polsoc.2015.03.004

Wu, J., \& Guo, D. (2015). Measuring E-government performance of provincial government website in China with slacks-based efficiency measurement. Technological Forecasting and Social Change, 96, 25-31. https://doi.org/10.1016/j.techfore.2015.01.007

Yang, K., \& Holzer, M. (2006). The performance-trust link: Implications for performance measurement. Public Administration Review, 66(1), 114-126. https://doi.org/10.1111/j.1540-6210.2006.00560.x

Yu, W., \& Ma, L. (2015). External government performance evaluation in China: a case study of the 'Lien service-oriented government project'. Public Money \& Management, 35(6), 431-437. https://doi.org/10.1080/09540962.2015.1083689

Yu, W., \& Ma, L. (2015). External Government Performance Evaluation in China: Evaluating the Evaluations. Public Performance \& Management Review, 39(1), 144-171. https://doi.org/10.1080/15309576.2016.1071171

\section{Notes}

Note 1. The values for the year 2015 are partial since publications are updated in May 2015.

Note 2. The table only shows the countries in which are published at least 2 of the 35 pre-selected articles. 